\title{
Defining the Scope of Grievance Arbitration in Public Education Employment Contracts
}

Unionization and collective bargaining for public employees are now accepted parts of American labor relations. ${ }^{1}$ Many states have statutes authorizing organization and negotiations, ${ }^{2}$ and in a number of states without these statutes, judicial decisions have approved collective bargaining between a public employer and a union of public employees. ${ }^{3}$

In the public sector, as in the private sector, disputes develop about the proper interpretation and application of collective bargaining agreements. A well established procedure for settling disputes in the private sector is grievance arbitration. ${ }^{4}$ Arbitration provides a useful middle ground between the protracted process of court enforcement and the industrial strife that might result unless there is a means of enforcing collective bargaining agreements. ${ }^{5}$ The use of arbitration as the final step in the grievance procedure of a public employment contract is a logical corollary of the private sector experience. Indeed, the fact that strikes are generally prohibited in the public sector ${ }^{b}$ makes a

1 Edwards, The Emerging Duty to Bargain in the Public Sector, 71 Micr. L. REv. 885 (1973); Smith, State and Local Advisory Reports on Public Employment Labor Legislation: A Comparative Analysis, 67 Mrcr. L. Rev. 891, 892 (1967).

2 See BNA Government Employees Rerations Reporter Reference File 51:501 et seq. (1973) (summary of state public employee bargaining statutes); Blair, State Legislative Control over the Conditions of Public Employment: Defining the Scope of Collective Bargaining for State and Municipal Employees, 26 VAND. L. REv. 1, 3 n.18 (1973).

3 Chicago Div. of Ill. Educ. Ass'n v. Board of Educ., 76 Ill. App. 2d 456, 222 N.E.2d 243 (1966). See also Norwalk Teachers' Ass'n v. Board of Educ., 138 Conn. 269, 83 A.2d 482 (1951); East Chicago Teachers v. Board of Trustees, 287 N.E.2d 891 (Ind. Ct. App. 1972); Gary Teachers v. School City of Gary, 284 N.E.2d 108 (Ind. Ct. App. 1972). See generally Dole, State and Local Public Employee Collective Bargaining in the Absence of Explicit Legislative Authorization, 54 IowA L. Rev. 539 (1969); Edwards, supra note 1, at 888-89 (the author discusses arguments that support imposition of a duty to bargain upon public employees despite the absence of a bargaining statute).

4 Grievance arbitration provisions usually confine the arbitrator to issues arising under the agreement-disputes about the application, interpretation, or construction of the collective bargaining agreement. Some grievance provisions, however, cover only certain types of disputes.

5 United Steelworkers of America v. Warrior \& Gulf Navigation Co., 363 U.S. 574, 578 (1960). See F. Elkouri \& E. Elkouri, How Arbitration Works 5-12 (3d ed. 1973); "Pickets at Crry Hall"-Report and Recommendations of the Twentieth Century Fund Task force on Labor Disputes in Public Employment, reprinted in BNA GoverNMENT EMployees ReLattons Reporter RefErence FiLe 51:151, 51:154 (1970) [hereinafter cited as Pickets at City halr].

$B$ "No public employee or employee organization shall engage in a strike, and no public 
neutral and effective dispute settlement device essential ${ }^{7}$ to guarantee substantive content for the organizational and bargaining rights of public employees. ${ }^{8}$

Although public sector grievance arbitration is permitted in most states by either statute ${ }^{9}$ or judicial decision, ${ }^{10}$ there is some question about the types of issues that may be the subject of arbitration. In reviewing public education collective bargaining agreements, courts have indicated that there are certain categories of disputes that cannot be submitted to an arbitrator for determination because the arbitrator would be assuming powers entrusted exclusively to the local school board by statute or regulation. ${ }^{11}$ This position discourages negotiation

employee or employee organization shall cause, instigate, encourage, or condone a strike." N.X. CIV. SERV. LAW \& 210(1) (Mckinney 1973). See also REPORT OF ADVISORY COMM'N ON INTERgovernmental RELATIONS: LABOR-MANagEMENT Policies for Statz AND LOCAL GOVERNMENTS, reptinted in BNA GOVERNMENT EMPLOYEES RELATIONS REPORTER REFERENCE File 51:101, 51:102 (1970) [hereinafter cited as LABor-Management Polictes]; K. Hanslowe, The Emerging LaW of Labor Relations in PUblic Eampoyment 12 (1967); Annot., 31 A.L.R.2d 1142, 1159-61 (1953).

7 "Complete effectuation of the federal policy is achieved when the agreement contains both an arbitration provision for all unresolved grievances and an absolute prohibition of strikes, the arbitration agreement being the 'quid pro quo' for the agreement not to strike." United Steelworkers of America v. Warrior \& Gulf Navigation Co., 363 U.S. 574, 578 n.4 (1960).

8 Labor-Management Policies, supra note 6, at 51:116.

9 Fourteen of the bargaining statutes that affect public education provide for either a negotiable or a mandatory grievance procedure. ALASKA STAT. § 14.20.590 (1973); HAwAII Rev. Laws \$ 89-10 (Supp. 1971); Kan. Stat. AnN. \$ 72-5424 (1973); Me. Rev. Stat. AnN. tit. 26, $\$ 969$ (Supp. 1973); MD. ANN. Code art. 77, § 160(h)(2) (Supp. 1973); MAss. ANN. Laws ch. 150E, § 8 (Supp. 1973); MinN. Stat. ANn. \& 179.70 (Supp. 1974); Mont. Rev. Codes ANn. \$ 75-6116 (1971); N.J. Rev. StAT. \& 34:13A-5.3 (Supp. 1974); N.Y. Crv. SERv. LAW §§ 200c \& 203 (McKinney 1973); PA. Stat. ANN. tit. 43, § 1101.903 (Supp. 1974); S.D. Comprnfe Laws ANn. \$§ 3-18-1.1 \& 3-18-15 (Supp. 1973); Vt. Stat. ANn. tit. 16, § 2004 (Supp. 1973); WIs. STAT. ANN. \$§ $111.70(1)$ (i) \& 111.70(4)(b)(2) (1974).

10 In several states in which the bargaining statute is silent on grievance procedures, judicial decisions have authorized grievance arbitration. See West Hartford Educ. Ass'n v. DeCourcy, 162 Conn. 566, 295 A.2d 526 (1972); Local 953, AFSCME v. School District, Gov'T EMP. ReL. REP. No. 216, at E-1 (Mich. Gir. Ct., Oct. 30, 1967); Board of Educ. v. Associated Teachers of Huntington, Inc., 30 N.Y.2d 122, 331 N.Y.S.2d 17, 282 N.E.2d 109 (1973); Local 1226 v. Rhinelander, 35 Wis. 2d 209, 151 N.W.2d 30 (1967). In several states in which collective bargaining for teachers is allowed by judicial decision, courts have permitted grievance arbitration. See Norwalk Teachers' Ass'n v. Board of Educ., 138 Conn. 269, 83 A.2d 482 (1951); East Chicago Teachers v. Board of Trustees, 287 N.E.2d 891 (Ind. Ct. App. 1972); Gary Teachers v. School City of Gary, 284 N.E.2d 108 (Ind. Gt. App. 1972).

11 Chief of Police v. Town of Dracut, 357 Mass. 492, 502-03, 258 N.E.2d 531, 538-39 (1970); Lehman v. Dobbs Ferry Bd. of Educ., 66 Misc. 2d 996, 1002, 323 N.Y.S.2d 283, 289 (Sup. Ct. 1971). If the school board agreed to submit all disputes to arbitration "it might find itself committed to surrender the broad discretion and responsibility reposed in it by law." Norwalk Teachers' Ass'n v. Board of Educ., 138 Conn. 269, 279, 83 A.2d 482, 487 (1951). 
of grievance arbitration provisions in public education employment contracts and may discourage prosecution of grievances all the way to arbitration. ${ }^{12}$

This comment considers the proper scope of grievance arbitration. under collective bargaining agreements in public education. ${ }^{13}$ After examining the case law in this area, the comment concludes that the scope of grievance arbitration should be coextensive with the scope of collective bargaining. ${ }^{14}$ This broad scope of grievance arbitration can be achieved without destroying a school board's ability to manage its schools.

\section{Judicial Interpretattons of the Scope of Grievance Arbitration}

In public and private sector labor disputes, a grievance is arbitrable only if the parties have agreed in their contract that the grievance at issue would be submitted to arbitration. ${ }^{15}$ In the public education area,

12 "Arbitration is a stabilizing influence only as it serves as a vehicle for handling any and all disputes that arise under the agreement." United Steelworkers of America v. American Mfg. Co., 363 U.S. 564, 567 (1960).

13 A majority of the states have enacted statutes dealing with collective bargaining in public education. Alaska Stat. \& 14.20 .560 (1973); CaL. Educ. Code § 13085 (West Supp. 1974); Conn. Gen. Stat. AnN. §§ 10-153a \& 10-153d (Supp. 1973); Dex. Code AnN. tit. 14, $\S 4000$ (Supp. 1970); Fla. Stat. ANN. § 839.221 (1965); HawaII Rev. Laws $\$ 89$ et seq. (Supp. 1971); Kan. Stat. ANn. § 72-5414 (1973); ME. REv. Stat. ANn. tit. 26, § 965 (Supp. 1973); Mo. ANn. Code art. 77, § 160 (Supp. 1973); MAss. ANn. LAws ch. 150E, \& 2 (Supp. 1973); Mrah. Stat. ANN. § 17.455(9) (1968); MinN. StAT. ANN. § 179.65 (Supp. 1974); MonT. Rev. Codes ANn. § 75-6119 (1971); NEb. Rev. Stat. \$\$ 79-1287 et seq. (1968); Nev. StAT. § 288.150 (1973); N.H. Rev Stat. ANN. § 98-C:5 (Supp. 1973); N.J. Rev. Stat. § 34:13A-5.3 (Supp. 1974); N.Y. Crv. SERv. LAW §§ 200 et seq. (McKinney 1973); N.D. CENT. CODE § 1538.1 (1971); ORLA. Stat. ANN. tit. 70, §§ 509.1 et seq. (1972); Pa. Stat. ANn. tit. 43, §§ 1101.901 et seq. (Supp. 1974); R.I. GEN. LAws ANN. § 28-9.3 (Supp. 1973); S.D. CoMpIIED Laws ANN. § 3-18 (Supp. 1973); VT. Stat. ANN. tit. 16, § 1982 (Supp. 1973); Wash. Rev. CODE ANN. § 28A.72.030 (1970); Wis. STAT. ANN. \& 111.70(2) (1974). In other states, collective bargaining is authorized by judicial decision. See note 3 supra.

14 The problem of the proper scope of arbitration does not arise when the employment contract lacks an arbitration provision or when the provision clearly fails to apply to the dispute at issue.

15 Axbitrability questions are more common in the public sector than in the private sector. See Masters, The Arbitrability Issue in Michigan School Disputes, 28 ARB. J. (n.s.) 119,120 (1973). Although grievance arbitration provisions are common in the private sector, they have not been fully accepted in the public sector. Collective bargaining is a recent development in the public sector, and there have been doubts about the enforceability of agreements to arbitrate. Krislov \& Peters, The Arbitration of Grievances in Educational Units in the Late 1960's, 23 LAB. L.J. 25, 26 (1972). Furthermore, the powers and duties of a public employer, unlike those of a private employer, are specified by statute. See, e.g., Conn. Gen. Stat. ANN. \$§ 10-220 et seq. (Supp. 1973); ILL. Rev. Stat. ch. 122, $\S \S 10-20.1$ to 10-23.9 (1973); N.Y. Educ. LAw $\S 3001$ et seq. (McKinney 1973). Not all areas of authority can be negotiated in collective bargaining. See generally CoNN. GEN. STAT. ANN. § 10-153d (Supp. 1973) (hours of employment excluded from the scope of bargaining); PA. Stst. ANN. tit. 43, \$1101.702 (Supp. 1974) (defining the area of managerial discretion that cannot be the subject of bargaining). 
courts frequently question submission of issues to arbitration on an additional ground; it is often asserted that a grievance is not arbitrable when exclusive control over the matter at issue has been statutorily granted to the local school board. ${ }^{18}$

The basic problem confronting the courts, therefore, is to accommodate contractual provisions for grievance arbitration to statutes vesting management and control of educational matters in local school boards. ${ }^{17}$ The rule that the courts have apparently established substantially narrows the scope of grievance arbitration in public education.

In a series of cases in New York, the courts have indicated that a grievance is not arbitrable if the arbitrator's decision involves the exercise of a power statutorily vested in the local school board. In Legislative Conference v. Board of Higher Education, ${ }^{18}$ the court, after determining that a grievance concerning tenure pertained to a matterteacher appointments-that the board did not have power to bargain over and that the parties had not agreed to arbitrate, ${ }^{18}$ relied on the argument that the grievance was not arbitrable because a state statute had imposed on the school board the duty to hire on the basis of merit and fitness. ${ }^{20}$ The court concluded that the state statute authorizing collective bargaining was not intended to allow the board to delegate that duty to an arbitrator. ${ }^{21}$

In Lehman v. Dobbs Ferry Board of Education, ${ }^{22}$ the court considered a grievance that the parties had not agreed to arbitrate. ${ }^{23}$ It concluded that the grievance, which concerned the discharge of a school nurse on probationary status, was not arbitrable because the school board was better qualified to make a discharge determination and because contractual delegation to an arbitrator of a matter of such vital public importance would be void as contravening major public policy. ${ }^{24}$

16 See generally Krinsky, Municipal Grievance Arbitration in Wisconsin, 28 ARB. J. (n.s.) 50 (1973); Masters, supra note 15, at 123.

17 "The key questions that must be decided are: Whether the administrative authority over employment conditions traditionally exercised by public officials should now be shared with public employees ... ." Pickets AT CrTY Hill, supra note 5, at 51:152. See generally LABOR-MANAGEMENT PoLiciss, supra note 6, at 51:123.

1838 App. Div. 2d 478, 330 N.Y.S.2d 688 (1972).

19 Id. at $479-80,330$ N.Y.S.2d at 690.

$20 \mathrm{Id}$. at 480,330 N.Y.S.2d at 691.

21 Id.

2266 Misc. 2d 996, 323 N.Y.S.2d 283 (Sup. Ct. 1971).

23 Id. at 1000-01, 323 N.Y.S.2d at 288.

24 Id. at 1002, 323 N.Y.S.2d at 289. The court in Lehman relied upon a similar decision in Board of Educ. v. Associated Teachers of Huntington, Inc., 36 App. Div. 2d 753, 319 N.Y.S.2d 469 (1971), which held that a teacher dismissal grievance was not arbitrable for the same two reasons. Although the court of appeals subsequently modified the lower court decision in Huntington, 30 N.Y.2d 122, 331 N.Y.S.2d 17, 282 N.E.2d 109 (1972), the 
Although the nature of this policy was not specified, the court presumably meant that arbitration of that grievance would infringe the policy of public control of the schools. ${ }^{25}$

Massachusetts courts also seem to indicate that some issues that a school board is free to include in a collective bargaining agreement may not be submitted to arbitration. In Doherty $v$. School Committee, ${ }^{20}$ the court held that an arbitrator could not order the reappointment of an athletic coach for the school year despite an agreement on appointments between the union and the school board. The court concluded that "initiation of the appointment in question lay in the discretion of the superintendent of schools." 27

School boards in states without statutes authorizing collective bargaining can agree to include a grievance arbitration provision in a contract if the courts permit collective bargaining. ${ }^{28}$ But in Norwalk Teachers' Association v. Board of Education, ${ }^{29}$ one of the earliest cases allowing grievance arbitration in public education employment contracts, the Connecticut Supreme Court held that a school board could not agree to submit all disputes to arbitration because the board would in effect surrender the discretion reposed in it by statute. ${ }^{30}$ The court held that the board could agree to arbitrate only specific disputes as they arose; if the teachers' union proposed submission of a dispute to

court of appeals decision can be read as holding only that the particular arbitration provision at issue was permissible because it complemented existing appeal procedures that had been created by statute for tenured teachers. See id. at 131, 331 N.Y.S.2d at 24, 282 N.E.2d at 114. The lower court in Legislative Conference adopted the limitations on the scope of arbitration stated by the appellate division in Huntington and distinguished the court of appeals decision on the ground that it involved a tenured teacher. Legislative Conference v. Board of Higher Educ., 38 App. Div. 2d 478, 481, 330 N.Y.S.2d 688, 691 (Sup. Ct. 1972). One lower court has interpreted the court of appeals decision in Euntington as implying a public policy limitation on the types of issues that may be decided - by an arbitrator. Board of Educ. v. Byram Hills Teachers' ${ }^{-}$Ass'n, 74 Misc. 2d 621, 622, 345 N.Y.S.2d 302, 304 (Sup. Ct. 1973).

An attempt to avoid conflict with statutory provisions may have prompted the holdings in Legislative Conference and Lehman that the parties had not intended to submit the issue to arbitration. A court should not decide an issue if the parties agreed to submit the issue to arbitration. United Steelworkers of America v. Warrior \& Gulf Navigation Co., 363 U.S. 574 (1960). This is also the rule in New York. Howard \& Co. v. Daley, 27 N.Y.2d 285, 317 N.Y.S.2d 326, 265 N.E.2d 747 (1970); Long Island Lumber Co. v. Martin, 15 N.Y.2d 380, 259 N.Y.S.2d 142, 207 N.E.2d 190 (1965).

25 Evidence of this is provided by the court's statement that: "It is this right to run the district that is at the heart of this dispute." 66 Misc. $2 \mathrm{~d}$ at 1000, 323 N.Y.S.2d at 287 (Sup. Ct. 1971).

26297 N.E.2d 494 (Mass. App. Ct. 1973).

27 Id. at 495.

28 See cases cited at note 3 supra.

29138 Conn. 269, 83 A.2d 482 (1951).

$30 \mathrm{Id}$. at $279-80,83 \mathrm{~A} .2 \mathrm{~d}$ at 487. 
arbitration, the board must have the opportunity to decide whether it would agree to arbitration.31 Thus, the school board could not agree to arbitrate all disputes arising from negotiated contract provisions.

A similar result was reached in an Illinois case, Board of Education v. Rockford Education Association, Inc., ${ }^{32}$ which held that a grievance claiming that a promotion had been improperly denied was not arbitrable. Although the court found nothing in the collective bargaining agreement indicating that the parties intended to submit disputes of that description to arbitration, it stated that the board did not have the power to enter into such an agreement.

However, a board may not, through a collective bargaining agreement or otherwise, delegate to another party those matters of discretion that are vested in the board by statute. The School Code provides that the board has the duty "To appoint all teachers and fix the amount of their salaries...."

-...

... [G]learly the Board could not, in any event, agree to limit those powers granted exclusively to it by the School Act. ${ }^{33}$

The court thus concluded that a contract provision limiting the board's power to appoint falls outside the scope of bargaining and that grievances under the provision could not be enforced through arbitration. ${ }^{34}$

These decisions may be based on a conclusion that the grievance derived from a contract provision that was not enforceable either because it was outside the scope of bargaining or because the grievance was not covered by the contract. ${ }^{35}$ Although no court has expressly held

31 Id.

323 III. App. 3d 1090, 280 N.E.2d 286 (1972).

$33 \mathrm{Id}$. at 1093, 280 N.E.2d at 287.

34 Board of Trustees v. College Teachers, 81 L.R.R.M. 2522 (1972), held, relying on Rockford, that an arbitrator could hear a grievance filed by several dismissed teachers who claimed that they had not been accorded certain procedures provided by their collective bargaining agreement. $I d$. at 2527-29. The court concluded that the arbitrator could, if he found for the teachers, enter an award that required the board to follow the contract procedures; but he could not teverse the dismissals and order a renewal of the contracts because the board's power to make appointments cannot be delegated or limited by contract. Id. at 2527-29.

35 A similar analysis of other cases in which the court's reasoning for arbitrability decisions is unclear indicates that the basis for each decision is the court's determination of the permissible scope of collective bargaining. For instance, Teachers Ass'n v. Board of Educ., 34 App. Div. 2d 351, 312 N.Y.S.2d 252 (1970), held that a grievance relating to the payment of accumulated sick leave to a deceased teacher's estate was arbitrable because the dispute concerned the application of a bargainable sick leave provision and was not an unconstitutional gift of funds. Board of Educ. v. Chautauqua Teachers Ass'n, 41 App. Div. 2d 47, 341 N.Y.S.2d 690 (1973), ordered arbitration for a teacher whose grievance was that he had not been accorded the evaluation procedures required by contract. The court said that if the arbitrator found that the board had failed to comply with the pro- 
that the scope of grievance arbitration is narrower than the scope of collective bargaining, there are strong and repeated indications in the cases that there may be issues that the board could submit to bargaining but not to arbitration. ${ }^{36}$ The reasoning behind this position is not untenable, but the preferable approach is to allow a school board to submit to arbitration all disputes that arise from contract provisions over which the board had power to bargain.

\section{An Expansive Approach to Grievance Arbitration in Public Education}

Restrictions on the scope of grievance arbitration ${ }^{37}$ imposed by state courts appear to have been motivated by a concern that arbitration could interfere with the operation of a school system by intruding into areas in which school boards have traditionally exercised unilateral control pursuant to statute. ${ }^{38}$ Commentators have expressed the view that it is both unwise and improper to remove from the people, as represented by the school board, powers vested in them by law or tradition. ${ }^{30}$

The result of this restrictive approach is that a board can delegate some of its powers to teachers through collective bargaining over the terms and conditions of employment, ${ }^{40}$ but cannot further delegate its

cedure's requirements, he could reinstate the teacher for a reasonable time during which the board could comply with the evaluation procedures. After compliance, the board could exercise its statutory authority to determine the teacher's competence. This case indicates that although the evaluation procedures were bargainable and thus arbitrable, the final determination of competence was a power that the board could not delegate or limit by contract, and therefore an arbitrator could not make the determination for the board. Board of Educ. v. West Islip Teachers Ass'n, 68 Misc. 2d 830, 328 N.Y.S.2d 266 (Sup. Ct. 1972), stayed arbitration sought by teachers on the question of whether they could receive retroactive contractual salary and wage benefits that went unpaid during the period of federal wage stabilization. The court said that the teachers could not compel the board to arbitrate this issue notwithstanding the contract's grievance procedure because federal price controls preempted the bargaining agreement. The preemptive effect of the Phase $I$ freeze temporarily removed this issue from the scope of bargaining.

36 For example, if a statute provides that the power to make appointments is vested exclusively in the board, an appointment grievance could not be submitted to arbitration even though the board was free to include an appointment procedure clause in the contract.

37 See notes 18-34 supra.

38 Comment, Legality and Propriety of Agreements to Arbitrate Major and Minor Disputes in Public Employment, 54 CORNELL X. REV. 129, 135 (1968) [hereinafter cited as Major and Minor Disputes].

39 Stone, Introduction to ARbirration CASES IN Public EMployment vii, xiii (E. Tracy ed. 1969); Shenton, Compulsory Arbitration in the Public Service, 17 LAB. L.J. 198, 139 (1966). See also Norwalk Teachers Ass'n v. Board of Educ., 138 Conn. 269, 278-79, 83 A.2d 482, 486 (1951).

40 See text and notes at notes 3-10 supra. 
statutory authority to an arbitrator. In negotiating a contract, the school board, though subject to bargaining pressures, retains statutory discretion to agree or refuse to agree to any demands made by the teachers and to refuse to make a concession. ${ }^{41}$ On the other hand, in grievance arbitration the decision of the arbitrator is a binding determination of the meaning of the contract and supersedes the unilateral discretion statutorily vested in the school board. The school board would in effect delegate its statutory authority to an arbitrator without retaining discretion to refuse to abide by the decision. ${ }^{42}$

Judicial limitation on the types of grievances that are arbitrable, however, is detrimental to the effectiveness of the settlement machinery, the enforcement of the contract, and the entire collective bargaining process. ${ }^{43}$ It is submitted that a scope of grievance arbitration that is coextensive with the scope of collective bargaining provides the advantages of grievance arbitration while preserving the school board's management function.

\section{A. Advantages of Grievance Arbitration}

Effective grievance arbitration has several practical advantages. First, because it is impossible to anticipate all disputes that might arise during the life of a contract and resolve them in the initial agreement, ${ }^{44}$ a grievance arbitration provision adds flexibility to the collective bargaining process. Second, it encourages careful decision making by the school board, since the board recognizes that contested decisions are subject to the arbitrator's scrutiny and binding determination. The same consideration may create incentives to settle grievances short of arbitra-

41 See, e.g., Conn. GEN. STAT. ANN. § 10-153d (Supp. 1973):

The town or regional board of education ... shall have the duty to negotiate with respect to salaries and other conditions of employment about which either party wishes to negotiate, ... but such [duty] shall not compel either party to agree to a proposal or require the making of a concession.

See also Mich. STAT. ANN. § 17.454(32) (1968):

For the purposes of this section, to bargain collectively is the performance of the mutual obligation of the employer and the representative of the employees to meet at reasonable times and confer in good faith with respect to wages, hours and other terms and conditions of employment ... but such obligation does not compel either party to agree to a proposal or require the making of a concession.

42 Several commentators have noted that this delegation of authority might be considered improper. See, e.g., R. DOHERTY \& W. ObERER, TEAchers, Schoor BoArd, and Collrctive Bargaining: A Changing of the Guard 123-24 (1967); Hilderbrand, The Public Sector, in Frontiers of Collective Bargaining 125, 145 (J. Dunlop \& N. ChamberLAIN eds. 1967); Fowlett, Resolution of Impasses in Employee Relations in Public Education, in Employer-Employe Relations in the Public Schools 116, 124 (R. Doherty ed. 1967); Stone, supra note 39, at xiii. See also text at note 36 supra.

43 See United Steelworkers of America v. American Mfg. Co., 363 U.S. 564, 567 (1960).

44 United Steelworkers of America v. Warrior \& Gulf Navigation Co., 363 U.S. 574, 57879 (1960). See also B. Meltzar, Labor Law: Cases, Materiats and Problems 747 n.k (1970); Stone, supra note 39 , at xii. 
tion. ${ }^{45}$ Most important, because the strike tactic is almost universally banned in the public sector, ${ }^{46}$ grievance arbitration is necessary to assure teachers that the rights they had bargained for will be protected and enforced. ${ }^{47}$ Grievance arbitration thus establishes the teachers' faith in the bargaining process; as faith in the bargaining process increases, disruptions take place less often. ${ }^{48}$

When a school board, which is sensitive to the educational needs and problems in its community, agrees to an arbitration provision to settle the disputes that arise during the life of a collective bargaining agreement, courts should defer, as with other administrative bodies, ${ }^{49}$ to the school board's judgment. The courts should find in the board's general statutory authority to manage the schools the power to agree to an arbitration provision. ${ }^{50}$

\section{B. Grievance Arbitration Preserves the School Board's Management Function}

Allowing the scope of grievance arbitration to be coextensive with the scope of bargaining does not abrogate the school board's ability to manage the schools. First, if a school board concludes that retention of control over a bargainable subject is important, it can refuse in good faith to agree on the issue or it can exclude the subject from the arbitration provision. Second, a school board cannot agree to submit nonbargainable ${ }^{51}$ subjects to arbitration; the contractual provision is void and

45 See Major and Minor Disputes, supra note 38, at 136.

46 See authorities cited at note 6 supra.

47 See text and note at note 5 supra.

48 "A major factor in achieving industrial peace is the inclusion of a provision for arbitration of grievances in the collective bargaining agreement." United Steelworkers of America v. Warrior \& Gulf Navigation Co., 363 U.S. 574, 578 (1960).

49 See generally K. Davis, Administrative Law Treatise $\$ 30.09$ (1958).

50 "Insofar as the board has the power to make such a contract it follows that it has the power to agree on a method and forum for the purpose of settling disputes arising under the terms of the contract." West Fartford Educ. Ass'n v. DeCourcy, 162 Conn. 566, 588,295 A.2d 526, 538 (1972). But an employment statute may not always establish an affirmative rationale for allowing grievance arbitration. A California decision, Plancentia Educ. Ass'n v. Board of Educ., 77 L.R.R.M. 3137 (Cal. Super. Ct. 1971), held that a school board has no authority to enter into a legally enforceable contract relating to grievance arbitration. The court said that the state's policy on negotiations in public education as expressed by the Winton Act, CAL. EDuc. CODE $\$ \S 13080$ et seq. (West Supp. 1974), narrowly circumscribes the powers of the school districts and does not authorize the school board to enter into a legally enforceable contract with employee organizations.

51 It has been held that a board of education does not require legislative authority to enter into a collective bargaining agreement and that such agreement is not against public policy. However, a board may not, through a collective bargaining agreement or otherwise, delegate to another party those matters of discretion that are vested in the board by statute. The School Code provides that the board has the duty "To appoint all teachers and fix the amount of their salaries ...." The cases have 
unenforceable because it exceeds the board's bargaining authority. ${ }^{52}$ An arbitrator would thus be authorized to consider only grievances relating to bargainable subjects.

If the scope of collective bargaining is broader than the scope of grievance arbitration, a disputed contract provision would be enforceable in the courts though not subject to arbitration. But in both arbitration and court adjudication a school board is required to accept the decision of a third party. Although it can be argued that a court, with its ability to apply and construe relevant cases and statutes, is better equipped than an arbitrator to interpret and enforce an agreement, an arbitrator can perform valuable nonjudicial functions. An arbitrator will consider and settle contract disputes that a court might be unwilling to entertain..$^{53}$ Furthermore, since an arbitrator is usually selected on the basis of the parties' confidence in his knowledge of the practices in their area of employment and their trust in his personal judgment, he can consider factors that are not expressed in the contract as criteria for judgment in order to reach a fair solution of the dispute. ${ }^{54}$ The ablest judge is not equally informed and cannot be expected to bring the same experience and competence to the dispute settlement process. ${ }^{55}$

Nevertheless, the arbitrator's function is confined to the interpretation and application of the agreement; he does not sit to dispense his own brand of justice. The arbitration award is legitimate only if it is essentially grounded in the negotiated agreement. Courts will refuse to enforce an award when the arbitrator fails to meet this obligation. . $^{\text {s }}$ This review does not mean, of course, that the initial interpretation and

held that these are among the powers and duties of a board that cannot be delegated or limited by contract.

Board of Educ. v. Rockford Educ. Ass'n, 3 Ill. App. 3d 1090, 1093, 280 N.E.2d 286, 287 (1972) (footnotes omitted). Legislative guides to the scope of bargaining are found in bargaining statutes. A fairly representative provision setting forth the limits of bargaining is PA. Stat. ANN. tit. 48, \& 1101.702 (Supp. 1974):

Public employers shall not be required to bargain over matters of inherent managerial policy, which shall include but shall not be limited to such areas of discretion or policy as the functions and programs of the public employer, standards of services, its overall budget, utilization of technology, the organizational structure and selection and direction of personnel.

62 See, e.g., Legislative Conference v. Board of Higher Educ., 38 App. Div. 2d 478, 330 N.Y.S.2d 688 (1972), in which the court overruled an arbitrator's award granting tenure to a teacher because the state's constitution and tenure statutes expressly gave the Board of Higher Education exclusive power over appointments.

63 United Steelworkers of America v. American Mfg. Co., 363 U.S. 564, 567 (1960).

54 United Steelworkers of America v. Warrior \& Gulf Navigation Co., 363 U.S. 574, 582 (1960).

55 Id.

56 United Steelworkers of America v. Enterprise Corp., 363 U.S. 593, 597 (1960). 
application of the agreement is an issue for the court to settle. The courts should not assume the arbitrator's function of initially construing and applying the terms of a contract.

\section{Conclusion}

Effective grievance arbitration is essential if a collective bargaining agreement is to create a stable employment relationship. Indications in judicial decisions that the scope of grievance arbitration is narrower than the scope of bargaining unnecessarily inhibit effective arbitration. The scope of grievance arbitration in public education should be coextensive with the scope of collective bargaining. This approach would allow effective use of grievance arbitration to stabilize the employment relationship, maintain the teachers' faith in the bargaining process, and allow the school board to retain its authority to direct the operation of the schools.

David E. Shipley 